Correction

\title{
Correction: Sidawi, B. The Impact of Social Interaction and Communications on Innovation in the Architectural Design Studio. Buildings 2012, 2, 203-217
}

\section{Bhzad Sidawi}

College of Architecture and Planning, University of Dammam, 31451 Dammam, P.O. Box 2397, Saudi Arabia; E-Mail: Bsidawi@ud.edu.sa; Tel.: +966-3-8577000; Fax: +966-3-8578739

Received: 15 May 2014 / Accepted: 16 May 2014 / Published: 23 May 2014

The author wishes to make the following corrections to [1]. Due to mislabeling, replace References 31 and 33:

31. Salamah, A. A process oriented design pedagogy: KFUPM sophomore studio. CEBE Trans. 2005, $2,16-31$.

33. Salamah, A. New Trends in Architectural Education: Designing the Design Studio; Tailored Text and Unlimited Potential Publishing: Raleigh, NC, USA, 1995.

with

31. Salama, A.M. A process oriented design pedagogy: KFUPM sophomore studio. CEBE Trans. 2005, 2, 16-31.

33. Salama, A.M. New Trends in Architectural Education: Designing the Design Studio; Tailored Text and Unlimited Potential Publishing: Raleigh, NC, USA, 1995.

The authors would like to apologize for any inconvenience caused to the readers by these changes.

\section{Reference}

1. Sidawi, B. The Impact of Social Interaction and Communications on Innovation in the Architectural Design Studio. Buildings 2012, 2, 203-217.

(C) 2014 by the authors; licensee MDPI, Basel, Switzerland. This article is an open access article distributed under the terms and conditions of the Creative Commons Attribution license (http://creativecommons.org/licenses/by/3.0/). 